Original Research Paper

\title{
Isolation and Analysis of Bioactive Compounds Endophytic Bacteria of Sea Fern (Acrtostichum aureum L.) from Bengkalis Island, Riau
}

\author{
Tetty Marta Linda ${ }^{1 *}$, Azizul Berlyansah ${ }^{1}$, Bernadeta Leni Fibriarti ${ }^{1}$, Nery Sofiyanti ${ }^{1}$, \\ Silvera Devi ${ }^{2}$ \\ 1Jurusan Biologi, Fakultas MIPA, Universitas Riau, Pekanbaru, Riau, Indonesia \\ ${ }^{2}$ Jurusan Kimia, Fakultas MIPA, Universitas Riau, Pekanbaru, Riau, Indonesia
}

\author{
Article History \\ Received : November $09^{\text {th }}, 2021$ \\ Revised : December $15^{\text {th }}, 2021$ \\ Accepted : December $24^{\text {th }}, 2021$ \\ Published : January $05^{\text {th }}, 2022$ \\ *Corresponding Author: \\ Tetty Marta Linda, \\ Jurusan Biologi, Fakultas MIPA, \\ Universitas Riau, Pekanbaru, \\ Riau, Indonesia \\ Email: \\ tetty.martalinda@lecturer.unri.ac.id
}

\begin{abstract}
Endophytic bacteria have been known to produce high levels of secondary metabolites. The sterile leaves of the sea fern (Acrostichum aureum L.) contain many phytochemical compounds. This sea fern is often found in peat swamp areas. The aim of this study was to isolate, partial characterization, and analysis of bioactive compounds from endophytic bacteria of sea ferns to determine their bioactive compounds. Endophytic bacteria were isolated by a direct technique using nutrient agar (NA) media. In this study, the endophytic bacteria were characterized by macroscopic, microscopic, and Gram. Several tests were further performed, namely phytochemical test and Fourier Transform Infra Red (FT IR) FTIR tests from a crude extract of secondary metabolites of bacteria. The results of the isolation obtained six isolates of endophytic bacteria consisting of all isolates were Gramnegative. The phytochemical test results for the six isolates were positive for alkaloids and saponins but no steroids. Based on the results of phytochemical tests and FT IR, it is suspected that the isolate DSB 1.6 has similarities with the alkaloid functional group. This endophytic bacterial isolate can be developed as a candidate for produced of pharmacological compounds.
\end{abstract}

Keywords: Endophytic bacteria, Peat swamp, Phytochemical, Sea fern

\section{Pendahuluan}

Tumbuhan Paku laut (Acrtostichum aureum L.) merupakan tumbuhan dengan habitat hidup di lahan basah seperti rawa gambut. Paku laut ini tersebar luas di daerah tropis seperti di Negara Brazil, Ekuador, Paraguay, India, Sri Langka, Bangladesh, Jepang, Taiwan, India, Malaysia, Fiji, Tiongkok serta Indonesia (Raja \& Ravindranadh, 2014). Lahan basah di Provinsi Riau terluas di pulau Sumatera yaitu 56,1\% kirakira 4,04 juta Ha dari keseluruhan luas lahan basah yang ada di Sumatera (Mubekti 2011).

Tumbuhan paku laut disebut juga dengan paku bakau yang tumbuh dengan baik pada lingkungan peralihan laut dan daratan (rawa) di pinggir pantai. Kawasan pantai Selatbaru Bengkalis adalah salah satu daerah pesisir di
Provinsi Riau yang merupakan kawasan rawa gambut. Menurut Nasrul (2010) sifat fisik tanah gambut di daerah Bengkalis berdasarkan derajat dekomposisinya tergolong gambut saprik dengan bobot isi berkisar $0,10-0,18 \mathrm{~g} / \mathrm{cm}^{3}$. Sifat kimia gambut dengan kemasaman tinggi dengan $\mathrm{pH}$ 3,54 - 4,0, kandungan C-organik 7,95-10,08\% dan N-total bervariasi antara 0,361-13\%. Keunikan habitat merupakan salah satu potensi untuk mengeksplorasi mikroba endofit dari tanaman paku laut yang dapat diaplikasikan dalam ilmu farmasi.

Tumbuhan rawa gambut telah banyak dilakukan uji kandungan fitokimia guna medeteksi metabolit sekunder dan aktivitasnya. Tumbuhan paku laut dari Puthalam, Kanyakumari District, Tamil Nadu ekstrak daunnya mengandung flavonoid steroid, saponin, 
fenol, dan terpenoid (Badhsheeba \& Vadivel, 2020), paku laut dari kawasan Tirupati-India dilaporkan memiliki senyawa fitokimia saponin, alkaloid, flavonoid dan steroid (Raja \& Ravindranadh, 2014), Hanin \& Pratiwi (2017) melaporkan bahwa daun steril dan fertil dari paku laut dari hutan mangrove Kulon Progo Yogyakarta mengandung senyawa fenolik dan flavonoid. Perbedaan lokasi pengambilan sampel menunjukkan kandungan fitokimia tanaman berbeda-beda.

Potensi fitokimia tanaman berkaitan erat dengan mikroorganisme yang hidup yang terdapat di dalam jaringan dasar tanaman seperti jaringan akar, batang, daun buah, bunga dan biji yang diketahui sebagai mikroba endofit. Mikroba endofit seperti bakteri ditemukan di dalam jaringan vaskuler pada inang tanaman (Kobayashi \& Palumbo, 2000) dan mikroba di dalam jaringan tanaman yang bersimbiosis tidak memberikan efek merugikan bagi inangnya (Rusli \& Rahmaniar, 2013). Simbiosis antara endofit dan tanaman dapat meningkatkan serapan hara dan ketahanan tanaman, sehingga mempengaruhi produksi metabolit sekunder (Maheshwari, 2017). Metabolit sekunder yang dihasilkan oleh mikroba endofit dapat dimanfaatkan sebagai antimikroba (Photolo et al., 2020), antibakteri (Rori, Kandau \& Tangapo, 2020), antioksidan (Triana, Sarjono \& Mulyani, 2017), antikanker (Anwar \& Futra, 2019), inhibitor $\alpha$-amilase (Chigurapati et al. 2019), $\alpha$ amilase (Pujiyanto et al., 2018), $\alpha$-glukosidase (Fatin, Pujianto \& Raharjo, 2018) sebagai senyawa antidiabetes.

Mikroba endofit dari tumbuhan rawa gambut di Riau sudah banyak dilaporkan. Isolasi mikroba endofit dari tanaman mangrove Ceriops tagal (Perr.) C.B. Rob dan Bruguiera dari daerah Pakning dan pantai Tegayun Kabupaten Bengkalis dilaporkan Haryani et al., (2019) yang mengisolasi 28 jamur endofit dan (Haryani et al., 2020) isolasi 95 bakteri endofit dan Lestari, Agustin \& Djamaan (2019) mengisolasi jamur endofit dari Avicennia marina di daerah Kuala Enok Indragiri Hilir, Provinsi Riau. Sejauh ini belum ada informasi tentang bakteri endofit dari paku laut dari rawa gambut Riau dan bioaktivitasnya.

Penelitian mikroba endofit rawa gambut dari Riau umumnya dari tanaman mangrove. Satu-satunya tumbuhan paku yang sering di kelompokkan ke mangrove adalah paku laut Acrostichum aureum L. dengan famili Pteridaceae karena habitat tumbuhnya sama. Hasil inventarisasi Sofiyanti et al., (2019) di Pulau Bengkalis ada 22 species paku salah satunya paku laut. Isolasi mikroba endofit dari paku-pakuan di Indonesia sebelumnya telah di laporkan diantaranya jamur endofit dari tumbuhan paku Asplenium nidus (Suhartina Kandou \& Singkoh, 2018), endofit bakteri dari tumbuhan paku air (Salvinia molesta), paku terestrial (Pteris ensiformis) dan paku epifit (Drymoglossum pilosolloides) oleh Asmoro \& Munif (2019).

Tujuan penelitian adalah mengisolasi dan karakterisasi bakteri endofit dari daun steril tumbuhan paku laut (Acrtostichum aureum L.) serta uji fitokimia ekstrak kasar bakteri. Penelitian ini diharapkan dapat memberi informasi aktivitas yang terkandung dari metabolit sekunder bakteri endofit daun paku laut (Acrostichum aureum L.) dari pesisir Pantai Selat Baru Kabupaten Bengkalis, Provinsi Riau.

\section{Bahan dan Metode}

\section{Tempat penelitian dan pengambilan sampel}

Penelitian ini di lakukan di Laboratorium Mikrobiologi Jurusan Biologi dan Laboratorium Biokimia Jurusan Kimia Fakultas Matematika dan Ilmu Pengetahuan Alam Universitas Riau mulai bulan Mei hingga November 2021. Sampel tumbuhan paku laut (Acrtostichum aureum L.) diambil di Kawasan pesisir pantai Selatbaru, Kabupaten Bengkalis, Provinsi Riau (Gambar 1). Sampel tanaman yang dipilih adalah tanaman paku laut (Acrtostichum aureum L.) dengan kriteria tumbuhan dewasa, memiliki daun steril dan sehat. Sampel tanamn diambil pada 3 titik lokasi, masing-masing tanaman diambil dengan dua ulangan. Sampel daun tumbuhan paku laut yang telah dipotong dimasukkan ke dalam sterile polyethylene bag diberi label dan disimpan ke dalam cool box yang telah diberi dry ice untuk di bawa ke laboratorium (Haryani et al., 2020). 


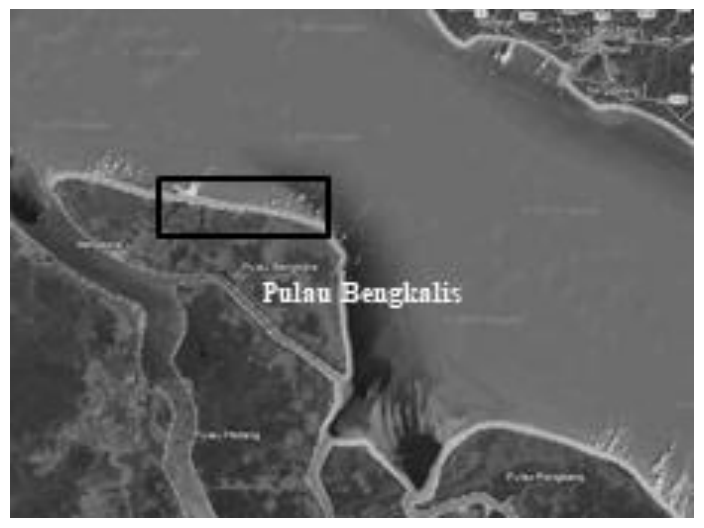

Gambar 1. Peta kawasan Pantai Selatbaru Kec. Bantan Kab. Bengkalis, Riau (Sumber: Peta satelit 2021).

\section{Isolasi bakteri endofit dari daun paku laut}

Isolasi bakteri endofit telah menggunakan sampel bagian daun tumbuhan paku laut yang sehat dengan ciri-ciri berwarna hijau, segar, tidak berjamur dan tidak ada luka bekas gigitan serangga. Sampel daun dilakukan sterilisasi permukaan dengan tahapan diawali dengan pencucian pada air mengalir hingga bersih selama $\pm 2-5$ menit. Daun di potong dengan ukuran $4 \times 4 \mathrm{~cm}$ menggunakan gunting steril. Potongan daun dilakukan sterilisasi bertingkat dengan tahap awal daun direndam ke dalam larutan etanol $70 \%$ selama 1 menit, tahap berikutnya dimasukkan ke larutan natrium hipoklorit dengan konsentrasi 5,25\% selama 5 menit selanjutnya dilakukan pembilasan menggunakan air destilasi steril sebanyak 3 kali. Potongan daun selanjutnya dikeringkan menggunakan kertas tisu steril.

Daun yang telah steril dipotong kembali dengan ukuran $2 \times 2 \mathrm{~cm}$. Masing-masing potongan daun di letakkan dalam cawan petri yang berisi medium Nutrient Agar (NA) untuk diinkubasi pada suhu ruang selama 48 jam. Sebagai kontrol sterilisasi permukaan sampel daun, air sampel bilasan ketiga sebanyak $1 \mathrm{~mL}$ dengan teknik spread plate diinokulasikan dalam cawan petri berisi media NA lalu diinkubasi selama 48 jam. Kontrol di buat dengan tiga ulangan. Isolasi bakteri endofit berhasil jika pada media kontrol tidak ditumbuhi oleh mikroorganisme di akhir inkubasi.

\section{Pemurnian dan karakterisasi bakteri endofit}

Isolat bakteri yang tumbuh pada pinggiran sampel daun dimurnikan dengan memindahkan menggunakan ose ke medium NA dengan teknik streak quadrant sehingga diperoleh koloni tunggal. Tiap-tiap koloni bakteri yang tumbuh dengan morfologi berbeda dilakukan pemisahan. Isolat bakteri yang telah murni selanjutnya disimpan pada medium NA miring dilemari pendingin suhu $4^{\circ} \mathrm{C}$ untuk digunakan pada tahapan berikutnya.

Karakterisasi parsial makroskopis bakteri endofit dari morfologi koloni meliputi pengamatan: warna, tepian, elevasi dan ukuran koloni. Karakterisasi biokimia telah di uji Gram dengan $\mathrm{KOH} 3 \%$, uji katalase dan pertumbuhan pada medium selektif de Man Rogosa and Sharpe (MRSA).

\section{Produksi senyawa metabolit sekunder}

Produksi senyawa metabolit sekunder isolat bakteri endofit dari tumbuhan paku laut merujuk pada metode Aristina, Astuti \& Pratiwi (2019) dengan modifikasi. Masing-masing inokulum bakteri sebanyak $10 \%$ (v/v) dengan populasi $10^{8} \mathrm{cfu} / \mathrm{mL}$ dimasukkan ke dalam $90 \mathrm{ml}$ nutrient both (NB). Selanjutnya media diinkubasi dalam shaker inkubator $150 \mathrm{ppm}$ selama 72 jam dengan suhu $30^{\circ} \mathrm{C}$. Di akhir waktu inkubasi, senyawa metabolit sekunder diproduksi dengan cara pemisahan dengan penyaringan menggunakan kertas saring Whatman no.42. Hasil fitrat dari proses penyaringan berupa ekstrak kasar metabolit sekunder dari isolat bakteri endofit yang selanjutnya digunakan untuk uji fitokimia dan analisis gugus fungsi. Masingmasing produksi metabolit sekunder isolat bakteri endofit dilakukan dengan tiga ulangan.

\section{Uji fitokimia}

Pengujian kandungan senyawa metabolit sekunder yang diuji pada penelitian ini adalah alkaloid, steroid dan saponin. Uji alkaloid menggunakan pereaksi Mayer. Ekstrak kasar metabolit sekunder sebanyak $5 \mathrm{~mL}$ ditambahkan dengan $2 \mathrm{~mL}$ kloroform dan amonia sebanyak 2 $\mathrm{mL}$ lalu dilakukan penyaringan. Filtrat selanjutnya ditambahkan dengan $\mathrm{H}_{2} \mathrm{SO}_{4}$ pekat sebanyak 3-5 tetes, lalu di kocok sehingga didapat dua lapisan. Lapisan bagian atas selanjutnya dipindahkan ke dalam tabung reaksi baru untuk tahap selanjutnya ditetesi preaksi Mayer sebanyak 4-5 tetes. Pengujian dilakukan dengan tiga ulangan. Hasil uji positif kandungan senyawa alkaloid ditandai dengan adanya 
perubahan warna larutan dari bening menjadi putih susu setelah pemberian pereaksi Mayer.

Uji steroid dilakukan masing-masing ekstrak kasar isolat bakteri endofit sebanyak 5 $\mathrm{mL}$ dimasukkan ke dalam testube lalu di tambahkan dengan asam asetat glasial sebanyak 10 tetes dan $\mathrm{H}_{2} \mathrm{SO}_{4}$ pekat 2 tetes. Tabung selanjutnya di kocok perlahan dan diinkubasi selama 1-2 menit. Masing-masing dilakukan uji dengan tiga ulangan. Hasil uji positif kandungan senyawa steroid ditandai perubahan warna hijaubiru. Masing-masing dilakukan uji dengan tiga ulangan.

Uji fitokimia saponin dilakukan ekstrak kasar bakteri endofit sebanyak $5 \mathrm{~mL}$ di tambahkan dengan $10 \mathrm{~mL}$ aquades steril dan lakukan pengocokan selama 1 menit. Hasil uji positif kandungan saponin dari masing-masing isolat bakteri endofit ditandai dengan terbentuknya busa yang stabil selama \pm 10 menit (Aristina et al., 2019).

\section{Uji analisis gugus fungsi metabolit sekunder}

Analisis gugus fungsi metabolit sekunder dari bakteri endofit di uji dengan menggunakan alat spektroskopi FTIR (Fourrier Transform Infra Red) (IRPrestige-21 Shimadzu) (Variani et $a l, .2021)$ dengan modifikasi.

\section{Hasil dan Pembahasan}

\section{Isolasi dan karakterisasi koloni bakteri}

Hasil isolasi bakteri endofit dari daun steril paku laut (Acrtostichum aureum L) ditandai dengan adanya pertumbuhan bakteri pada bagian pinggir-pinggir sampel daun yang di letakkan di dalam cawan petri seperti pada Gambar 2. Hasil dari pemurnian diperoleh enam isolat bakteri endofit dan karakterisasi koloni bakteri dapat di lihat pada Tabel 1.

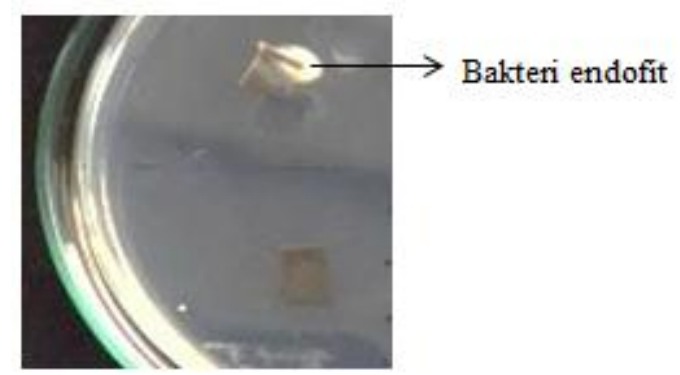

Gambar 2. Pertumbuhan bakteri endofit
Tabel 1. Karakterisasi koloni bakteri

\begin{tabular}{lcccc}
\hline \multirow{2}{*}{ Isolat } & \multicolumn{4}{c}{ Morfologi koloni } \\
\cline { 2 - 5 } & Warna & Pinggiran & Elevation & Ukuran \\
\hline DSB & putih & entire & flat & kecil \\
1.1 & susu & & & \\
DSB & putih & entire & raised & sedang \\
1.6 & susu & & & \\
DSB & putih & entire & flat & kecil \\
2.1 & susu & & & \\
DSB & putih & undulate & raised & sedang \\
3.1 & susu & & & \\
DSB & putih & entire & raised & kecil \\
4.1 & susu & & & \\
DSB & kuning & entire & convex & kecil \\
6.1 & & & & \\
\hline
\end{tabular}

Hasil penelitian ini serupa dengan penelitin Rori et al. (2020) yang berhasil mengisolasi tujuh bakteri endofit dari daun mangrove (Avicennia marina) yang dominan warna koloni putih dan Linda et al. (2018) melaporkan sembilan bakteri endofit dari daun tanaman karet dengan warna koloni putih dan kuning menggunakan medium isolasi NA. Medium lain yang dilaporkan untuk mengisolasi bakteri endofit dari paku adalah Trypsic Soy Agar (TSA) (Asmoro \& Munif, 2019; Tuo \& Yan, 2019), marine agar (Chen et al., 2021).

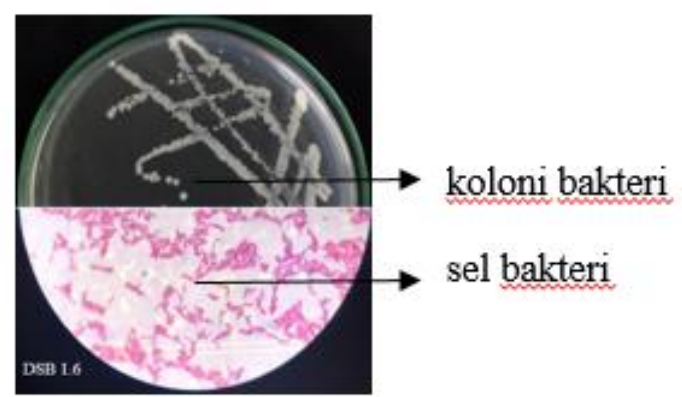

Gambar 3. Isolat bakteri DSB 1.6

Tabel 2 dan Gambar 3 hasil karakterisasi biokimia bakteri DSB 1.6 berbeda dengan kelima isolat lainnya dengan katalase negatif. Katalase negatif artinya tidak terjadi perombakan $\mathrm{H}_{2} \mathrm{O}_{2}$ oleh enzim katalase dan bakteri asam laktat adalah salah satu kelompok bakteri katalase negatif (Romadhon Subagyo \& Margino, 2012). Hal ini juga di dukung dengan kemampuan isolat DSB 1.6 tumbuh paling baik dibandingkan dengan keenam isolat lainnya pada medium selektif de Man Rogosa and Sharpe (MRSA) sebagai media selektif untuk bakteri asam laktat. 
Tabel 2. Karakterisasi biokimia bakteri

\begin{tabular}{cccc}
\hline \multirow{2}{*}{ Isolat } & \multicolumn{2}{c}{ Uji biokimia } & \\
\cline { 2 - 4 } & Gram & Katalase & MRSA \\
\hline DSB 1.1 & negatif & + & + \\
DSB 1.6 & negatif & - & ++ \\
DSB 2.1 & negatif & + & - \\
DSB 3.1 & negatif & + & + \\
DSB 4.1 & negatif & + & + \\
DSB 6.1 & negatif & + & - \\
\hline
\end{tabular}

\section{Uji Fitokimia}

Uji fitokimia merupakan uji awal untuk mengetahui kandungan senyawa metabolit sekunder yang terdapat di dalam ekstrak kasar bakteri endofit. Senyawa metabolit sekunder dapat digolongkan menjadi beberapa jenis berdasarkan struktur kimianya (Aristina et al., 2019).

Tabel 3. Hasil uji fitokimia

\begin{tabular}{rccc}
\hline \multirow{2}{*}{ Isolat } & \multicolumn{3}{c}{ Uji fitokimia } \\
\cline { 2 - 4 } & alkaloid & steroid & saponin \\
\hline DSB 1.1 & + & - & + \\
DSB 1.6 & + & - & + \\
DSB 2.1 & + & - & + \\
DSB 3.1 & + & - & + \\
DSB 4.1 & + & - & + \\
DSB 6.1 & + & - & + \\
\hline
\end{tabular}

Keterangan: $(+)=$ teridentifikasi;

$$
(-) \text { = tidak teridentifikasi }
$$

Hasil uji fitokimia ekstrak kasar metabolit sekunder ke enam isolat bakteri endofit paku laut menunjukkan positif mengandung senyawa alkaloid dan saponin Tabel 3. Hal ini disebabkan adanya perubahan warna putih susu yang terjadi pada uji alkaloid setelah ditambahkan pereaksi Meyer. Hasil uji positif saponin dengan terbentuknya busa dikarenakan adanya penguraian senyawa saponin menjadi glikosida dan senyawa lainnya, glikosida akan menyebabkan larutan berbusa (Marliana, Suryanti \& Suryono 2005). Keenam isolat ini tidak mengandung senyawa steroid karena tidak terjadi perubahan warna larutan menjadi hijaubiru.

Kandungan fitokimia yang di hasilkan dari ekstrak kasar bakteri endofit daun paku laut sejalan dengan hasil ekstrak kasar daun paku laut. Paku laut yang diekstraksi menggunakan etanol dan methanol dilaporkan menghasilkan saponin,
(Badhsheeba \& Vadivel, 2020), alkaloid dan saponin (Raja \& Ravindranadh, 2014) dan alkaloid, glikosida, tanin dan terpenoid hasil ekstraksi dengan etanol (Khan et al., (2013). Diduga kandungan nutrisi tanah di kawasan pengambilan sampel telah memberi pengaruh pada kandungan fitokimia tanaman dan fitokimia ekstrak kasar metabolik sekunder bakteri endofit. Selain itu, perbedaan hasil uji fitokimia ini diduga disebabkan oleh jenis bakteri, pelarut dan metode yang digunakan untuk mendapatkan ekstrak kasar metabolik sekunder yang berbeda.

Ekstrak kasar metabolit sekunder bakteri endofit dari batang tumbuhan pacing (Costus sp.) ditemukan 17 isolat bakteri endofit penghasil senyawa alkaloid, 15 isolat penghasil saponin dan 3 isolat penghasil steroid (Aristina et al., 2019), Variani et al., (2021) melaporkan ekstrak kasar Serratia marcescens strain MBC1 mengasilkan senyawa alkaloid dan saponin. Senyawa alkaloid, polifenol, tanin, flavonoid, kuinon dan saponin memiliki aktivitas antibakteri (Milanda, Lestari \& Tarina, 2021) dan saponin memiliki aktivitas antimalaria dan vibrosis (Matthew et al., 2018). Setyaningrum et al., (2021) melaporkan Streptomyces hygroscopicus subsp hygroscopicys strain I18 mengandung senyawa saponin yang dapat menghambat pertumbuhan plasmodium sehingga dapat dikembangkan sebagai antimalaria.

Hasil uji potensi biokimia dan fitokimia ekstrak kasar metabolit sekunder isolat DSB 1.6 dikarakterisasi struktur molekulnya menggunakan spektroskopi FTIR. Spektrum IR adalah jenis spektrum mengetahui gugus-gugus fungsional dari suatu molekul.

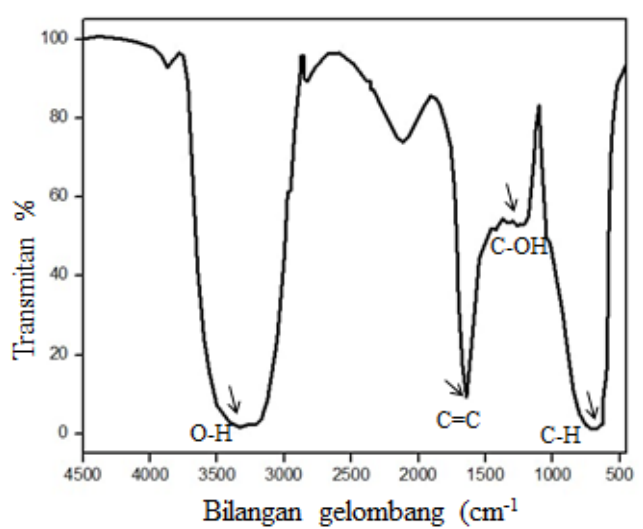

Gambar 4. Hasil spectrum FT IR ekstrak kasar isolat DSB1.6 
Hasil analisis FTIR pada Gambar 4. menunjukkan bahwa isolat DSB 1.6 memiliki empat puncak utama serapan spektrum yaitu 3197,09 - 3253,15 cm $\mathrm{cm}^{-1}, 1622,20 \mathrm{~cm}^{-1}, 1018,46$ $1200,74 \mathrm{~cm}^{-1}$ dan $645,22-702,12 \mathrm{~cm}^{-1}$. Serapan spektrum pada daerah bilangan 3197,09-3253,15 $\mathrm{cm}^{-1}$ menunjukkan adanya pita melebar yang merupakan vibrasi ulur dari gugus hidroksil dan membentuk ikatan hidrogen $(\mathrm{O}-\mathrm{H})$. Spektrum yang diperoleh melebar hal ini diduga karena adanya tumpang tindih (overlapping) yang terjadi dengan gugus fungsi pada beberapa bilangan gelombang spektra FTIR. Munculnya pita serapan pada bilangan gelombang 1622,20 $\mathrm{cm}^{-1}$ mengindikasikan adanya vibrasi regang gugus $\mathrm{C}=\mathrm{C}$ aromatik. Sedangkan pita serapan dengan puncak lemah pada bilangan gelombang 1018,46-1200,74 $\mathrm{cm}^{-1}$ menunjukkan adanya gugus $\mathrm{C}-\mathrm{OH}$ pada sampel. Spektrum pada bilangan gelombang 645,22-702,12 $\mathrm{cm}^{-1}$ menunjukkan adanya gugus $\mathrm{C}-\mathrm{H}$ pada sampel. Berdasarkan hasil analisis FTIR yang didapatkan diduga gugus fungsi dari ekstrak metabolit isolat DSB 1.6 memiliki kemiripan dengan senyawa alkaloid (Variani et al., 2021; Skoog, Holler \& Crouch, 2007).

\section{Kesimpulan}

Enam isolat bakteri endofit dari tumbuhan paku laut merupakan bakteri Gram negatif yang dapat menghasilkan senyawa bioaktif alkaloid dan saponin. Ekstrak kasar isolat DSB 1.6 analisi FTIR memiliki empat puncak utama serapan spektrum 3197,09-3253,15 $\mathrm{cm}^{-1}, 1622,20 \mathrm{~cm}^{-1}$, $1018,46-1200,74 \mathrm{~cm}^{-1}$ dan $645,22-702,12 \mathrm{~cm}^{-1}$ yang menunjukkan adanya kemiripan dengan gugus fungsi alkaloid.

\section{Kontribusi Penulis}

Penulis pertama: ide penelitian, koordinator pengambilan sampel, menyusun kerangka kerja, menyiapkan data di laboratorium, menyusun drafat artikel. Penulis kedua dan ketiga: membantu mengambil sampel dan pekerjaan di laboratorium untuk isolasi dan karakterisasi bakteri. Penulis keempat membantu mengidentifikasi sampel paku kuda Penulis kelima membantu pekerjaan di laboratorium uji fitokimia dan analisa data.

\section{Ucapan terima kasih}

Penulis mengucapkan terima kasih kepada Universitas Riau yang telah mendanai penelitian ini melalui hibah DIPA Universitas Riau dengan skim Penelitian Unggulan Universitas Riau 2021 atas nama penulis pertama.

\section{Referensi}

Anwar L \& Futra D. (2019). Potensi Metabolit Sekunder Produksi Bakteri Endofit dari Tumbuhan Laban (Vitex pubescens Vahl) Sebagai Antikanker. Chempublish Journal. 4 (2): 71-80. DOI:10.22437/chp. v4i2.7937.

Aristina RF, Astuti W \& Pratiwi DR. (2019). Skrining dan Uji Fitokimia Ekstrak Kasar Bakteri Endofit dari Batang Pacing (Costus sp). Jurnal Atomik 4(1): 21-24. DOI: https://doi.org/10.35799/jm.7.2.201 8.20640 .

Asmoro PP \& Munif A. (2019). Bakteri Endofit dari Tumbuhan Paku-pakuan sebagai Agens Hayati Rhizoctonia solani dan Pemacu Pertumbuhan Tanaman Padi. Jurnal Fitologi Indonesia. 15(6): 239247.

DOI: https://doi.org/10.14692/jfi.15.6.239 $-247$

Badhsheeba, MA \& Vadivel V. (2020). Physicochemical and Phytochemical Contents of the Leaves of Acrostichum aureum L. Journal of Global Biosciences. 9(4): $\quad$ 7003-7018. DOI: www.mutagens.co.in/jgb/vol.09/04/09040 7.pdf

Chen XH, He ZB, Li F, L SH, Li FN, Chen MS, Wu YL \& Tuo L. (2021). Nocardioides acrostichi sp. nov., a Novel Endophytic Actinobacterium Isolated from Leaf of Acrostichum aureum. Antonie van Leeuwenhoek. 114:479-486. https://doi.org/10.1007/s10482-02101535-5.

Chigurapati S, Vijayabalan S, Karunanidhi A, 
Selvarajan KK, Nanda SS \& Satpathy R. (2019). Antidiabetic, Antioxidant and in Silico Studies of Bacterial Endosymbiont Inhabiting Nephelium lappaceum. Ovidius University Annals of Chemistry. 30 (2): 95-100. DOI:10.2478/auoc-2019-0017

Fatin N, Pujiyanto S \& Raharjo B. (2018). Uji aktivitas Inhibisi $\alpha$-Glukosidase Isolat Bakteri Endofit Tanaman Duwet (Syzygium cumini L. Skeels) sebagai Sumber Alternatif Antidiabetes. Jurnal Bioma. $\quad 20 \quad$ (2): $\quad 165-169$. DOI.org/10.14710/bioma.20.2.165-169

Hanin NNF \& Pratiwi R. (2017). Kandungan Fenolik, Flavonoid dan Aktivitas Antioksidan Ekstrak Daun Paku Laut (Acrostichum aureum L.) Fertil dan Steril. Journal of Tropical Biodiversity and Biotechnology. $\quad 2$ : $\quad 51-56$. DOI.org/10.22146/jtbb.29819

Haryani Y, Hilma R, Delfira N, Linda TM, Puspita F, Friska A, Juwita D, Farniga A \& Ardi F. (2019). Potential Antibacterial Activity of Endophytic Fungi Penicillium sp. and Trichoderma sp. Derived From Mangrove Ceriops Tagal (Perr.) C.B.Robb and Bruguiera sp. Journal of Physics Conference Series 1351:012100. DOI: 10.1088/1742-6596/1351/1/012100.

Haryani Y, Hilma R, Delfira N, Linda TM, Puspita F, Friska A, Juwita D, Farniga A \& Ardi F. (2020). Antibacterial activity of Achromobacter sp. and Bacillus sp., bacterial endophytes derived from Mangrove Ceriops tagal (Perr.) C.B.Robb. IOP Conf. Ser.: Mater. Sci. Eng. 833 012013. DOI:10.1088/1757899X/833/1/012013.

Khan SA, Hossain MA, Panthi S, Asadujjaman M \& Hossin A. (2013). Assessment of Antioxidant and Analgesic Activity of Acrostichum aureum Linn. (FamilyPteridaceae). Pharmacologyonline 1: 166171.

https://www.semanticscholar.org/paper/A ssessment-of-antioxidant-and-analgesicactivity-of-Khan- ossain/27cf2742ab9b6d99b14012d45cea1 e55e8612b58.

Kobayashi DY \& Palumbo JD. (2000). Bacterial endophytes and their effects on plants and uses in agriculture. In: Bacon CW, White JF (eds.), Microbial Endophytes. pp 199233. ISBN: $\quad 9780429179334$ Marcel Dekker, Inc. New York, N.Y.

Linda TM, Siregar S, Fitri WD, Martina A, Lestari W, Roslim DI \& Hapsoh. (2018). Isolation and screening of culturable endophytic bacteria from leaf of rubber plant that produces of chitinase. Journal of Physics: Conf. Series 1116 - 052038. DOI:10.1088/1742-6596/1116/5/052038

Lestari K, Agustien A \& Djamaan A. (2019). The Potential of Endophytic Fungi Isolated from Leaves, Stems, Mangrove Roots Avicennia marina as a Producer of Antibiotics. Jurnal Metamorfosa 6 (1): 8389). DOI: 10.24843/metamorfosa.v06.i01.p13

Maheshwari DK (Ed). (2017). Endophytes: Biology and Biotechnology Volume 1. India: Springer Nature. DOI 10.1007/9783-319-66541-2

Marliana S, Suryanti V \& Suyono (2005). Skrining Fitokimia dan Analisis Kromatografi Lapis Tipis Komponen Kimia Buah Labu Siam (Sechium edule Jacq. Swartz.) dalam Ekstrak Etanol. Biofarmasi. 3 (1): 26-31. DOI: 10.13057/biofar/f030106

Matthew O, Olusola E, Ademola O, Aderotimi A \& Adebola J. (2018). Anti-malarial Activity of Total Saponins from Terminalia avicennioides and Its Effect on Liver and Haematological of Infected Mice. Drug Des 2018, 7(2):1-6. DOI: 10.4172/2169-0138.1000161

Milanda T, Lestari K \& Nimas TIT. (2021). Antibacterial Activity of Parijoto (Medinilla speciosa Blume) Fruit Against Serratia marcescens and Staphylococcus aureus. Indonesian Journal of 
Pharmaceutical Science and Technology $8(2)$ : 7685. DOI: https://doi.org/10.24198/ijpst.v $8 \mathrm{i} 2.32166$

Mubekti (2011). Studi Pewilayahan Dalam Rangka Pengelolaan Lahan Gambut Berkelanjutan di Provinsi Riau. Jurnal Sains dan Teknologi Indonesia. 13 (2): 8894. DOI: 10.29122/jsti.v13i2.883

Nasrul B. (2010). Penyebaran dan potensi lahan gambut di Kabupaten Bengkalis untuk pengembangan pertanian. Jurnal $\begin{array}{llll}\text { Agroteknologi } & 1 & \text { (1): } & 1-7 .\end{array}$ http://ejournal.uinsuska.ac.id/index.php/agroteknologi/articl e/view/5/5

Photolo MM, Mavumengwana V, Sitole L, \& Tlou MG. (2020). Antimicrobial and Antioxidant Properties of a Bacterial Endophyte, Methylobacterium radiotolerans MAMP 4754 Isolated from Combretum erythrophyllum Seeds. International Journal of Microbiology. 111. DOI.org/10.1155/2020/9483670

Pujiyanto S, Resdiani M, Raharja B \& Ferniah RS. (2018). $\alpha$-Amylase Inhibitor Activity of Endophytic Bacteria Isolated from Annona muricata L. Journal of Physics: Conference Series 1025. DOI: 10.1088/1742-6596/1025/1/012085

Raja S \& Ravindranadh K. (2014). Preliminary Phytochemical Screening of Different Solvent Extracts of Whole Plant of Acrostichum aureum. World Journal of Pharmaceutical Sciences. 2 (12): $1753-$ 1759.

http://www.wjpsonline.org/view_issue.ph p?title=Preliminary-phytochemicalscreening-of-different-solvent-extractsof-whole-plant-of-Acrostichum-aureum

Romadhon, Subagiyo \& Margino S. (2012). Isolasi dan Karakterisasi Bakteri Asam Laktat dari Usus Udang Penghasil Bakteriosin Sebagai Agen Antibakteria pada Produk-Produk Hasil Perikanan. Jurnal Saintek Perikanan 8 (1):59-64.
DOI: https://doi.org/10.14710/ijfst.8.1.5964

Rori CA, Kandou FEF \& Tangapo AM. (2020). Isolasi dan Uji Antibakteri Dari Bakteri Endofit Tumbuhan Mangrove Avicennia marina. Jurnal Koli. 1 (1):1-7. https://ojs3.unpatti.ac.id/index.php/koli/is $\underline{\text { sue/view/355 }}$

Rusli \& Rahmaniar D. (2013). Penelusuran Potensi Mikroba Endofit dari Rimpang Paku Kepala Tupai (Drynaria quercifolia J.Smith) sebagai Penghasil Senyawa Antibiotika. As-syifa Jurnal Farmasi. 5 (2): 128-139. https://jurnal.farmasi.umi.ac.id/index.php/ as-syifaa/issue/view/10

Setyaningrum E, Arifiyanto A, Nukmal N. (2021). In vitro Test for Inhibition of Plasmodium falciparum 3D7 Parasites using Streptomyces hygroscopicus subsp hygroscopicus Strain i18 Isolated from a Pineapple Farm in Lampung, J Pure Appl Microbiol. 15(2):891-896. DOI.org/10.22207/JPAM.15.2.45

Sofiyanti N, Isda MN, Juliantari E, Suriatno R, \& Pratama S. (2019). The Inventory and Spore Marphology or Ferns From Bengkalis Island, Riau Province, Indonesia. Jurnal Biodiversitas. 20 (11): 3223-3236.

DOI.org/10.13057/biodiv/d201115

Skoog DA, Holler FJ \& Crouch SR. (2007). Principles of Instrumental Analysis. Canada: David Harris Publisher. pp 455475. ISBN-13: 978-0-495-01201-6

Suhartina, Kandou FEF \& Singkoh MFO. (2018). Isolasi dan Identifikasi Jamur Endofit Pada Tumbuhan Paku Asplenium nidus. Jurnal FMIPA 7(2): 24-28. DOI: https://doi.org/10.35799/jm.7.2.201 8.20640

Tuo L \& Yan XR. (2019). Aureimonas flava sp. nov., a Novel Endophytic Bacterium Isolated from Leaf of Acrostichum aureum. Int J Syst Evol Microbiol. 
69:846-851.

10.1099/ijsem.0.003252.

Triana O, Sarjono PR, \& Mulyani NS. (2017). Isolasi Bakteri Endofit Pada Rimpang Jahe Merah (Zingiber offcinale Linn. Var Rubrum) Penghasil Senyawa Antioksidan. Jurnal Kimia Sains dan Aplikasi. 20 (1): 25-29. DOI.org/10.14710/jksa.20.1.25-29

Variani YA, Setyaningrum E, Handayani K, Nukmal N \& Arifiyanto A. (2021). Analisis Senyawa Bioaktif Ekstrak Metabolit Sekunder Serratia marcescens strain MBC1. Ind. J. Chem. Anal. 4 (2): 64-71. DOI: 10.20885/ijca.vol4.iss2.art3. 